\title{
Size AND SHAPE SeXUAl Dimorphism in the SKUll of the South American fur Seal, Arctocephalus australis (Zimmermann, 1783) (Carnivora: Otariddae)
}

\author{
Larissa Rosa de Oliveira ${ }^{1,2^{*}}$, Erika Hingst-Zaher ${ }^{3}$ and João Stenghel Morgante ${ }^{1}$
}

\begin{abstract}
We present a quantitative analysis of sexual dimorphism in the skull of Arctocephalus australis assessed by traditional and geometric morphometrics. Differences in size and shape of skulls of 386 adult males and females of A. australis from Uruguayan and Peruvian populations were analyzed using 15 linear measurements. These differences were also investigated applying geometric morphometrics techniques to two-dimensional images of 346 skulls in dorsal, ventral and lateral views. Results of traditional and geometric morphometrics revealed pronounced sexual dimorphism in size and shape of the skull for both populations of $A$. australis. Males are always larger than females, and differences in shape are concentrated mainly in the rostral region. Sexual dimorphism is more accentuated in the Uruguayan population. Differences in size and shape of the skulls between males and females of $A$. australis can be related to sexual selection, mating system and life history. In $A$. australis, as well as in other polygynous species, the selective pressures can favor the development of traits that enhance fighting ability in males, such as larger canines, increased rostral and mastoid widths and increased overall body size.

Resumo - Apresentamos uma análise quantitativa do dimorfismo sexual craniano de A. australis através de técnicas de morfometria tradicional e geométrica. Diferenças no tamanho e na forma dos crânios de machos e fêmeas de 386 espécimes adultos de $A$. australis das populações do Uruguai e Peru foram analisadas através de 15 medidas lineares. Estas diferenças também foram investigadas através das técnicas de morfometria geométrica aplicadas a imagens bidimensionais de 346 crânios nas posições dorsal, ventral e lateral. Os resultados tanto da morfometria tradicional quanto da geométrica indicaram a existência de um pronunciado dimorfismo sexual no tamanho e na forma dos crânios de A. australis de ambas as populações. Os crânios dos machos são sempre maiores do que os das fêmeas, e as diferenças na forma estão concentradas principalmente na região rostral. O dimorfismo sexual é mais acentuado na população do Uruguai. As diferenças na forma e no tamanho do crânio entre machos e fêmeas de A. australis podem estar associadas à seleção sexual, sistemas reprodutivos e a história de vida. Em A. australis, assim como em outras espécies poligínicas, as pressões seletivas podem favorecer o desenvolvimento de caracteres que aprimoram as habilidades de luta nos machos, tais como dentes caninos maiores, aumento na largura do rostro e do mastóide, assim como um aumento geral do tamanho do corpo.
\end{abstract}

Keywords: Arctocephalus australis, morphometrics, sexual dimorphism, shape, size, South American fur seal.

\section{Introduction}

Sexual dimorphism is very well documented in many species of pinnipeds and seems to be related to sexual selection (male competition) and highly polygynous mating systems (e.g. Berta and Sumich, 1999; Lindenfors et al., 2002). This phenomenon is observed mainly in external measurements reflecting body size and shape, and in secondary sexual characters (King, 1983; Berta and Sumich, 1999). Otariid seals represent the most dimorphic taxa among mammals (Weckerley, 1998), where males are two to four times larger than females (Riedman, 1990). The sexual dimorphism is also present among elephant seals (family Phocidae), in which fully adult males are up to 10 times larger than females (Le Boeuf and Laws, 1994), having also an enlarged proboscis and thicker skin on the neck.

Different mechanisms of sexual selection (e.g. female choice, contest competition and sperm competition) probably account for a large proportion of sexual dimorphism in marine mammals (Ralls and Mesnick, 2002). Based on studies of terrestrial mammals, a positive correlation is generally assumed between the amount of sexual dimorphism in a species and the deviation of the breeding system from monogamy. Thus, in polygynous species, male competition for access to females is severe and males can be expected to exhibit traits that would therefore favor them in threat displays or fights with other males over access to females, such as large body size and big canines. This correlation between size dimorphism and the degree of polygyny has been effectively shown across different pinniped taxa (Alexander et al., 1979; Lindenfors et al., 2002).

Sexual dimorphism has been documented in external traits, however only a few studies so far have explored the quantitative variation in size and shape of the skull and skeleton of otariids, all based on linear

\footnotetext{
${ }^{1}$ Universidade de São Paulo, Instituto de Biociências, Laboratório de Biologia Evolutiva e Conservação de Vertebrados (LABEC). Rua do Matão, 277, Cidade Universitária, São Paulo, SP 05508-090 Brazil.

${ }^{2}$ Grupo de Estudos de Mamíferos Aquáticos do Rio Grande do Sul (GEMARS). Rua Felipe Néri, 382/203, Porto Alegre, RS $90550-140$ Brazil. Centro de Estudos Costeiros, Limnológicos e Marinhos da Universidade Federal do Rio Grande do Sul (CECLIMAR/UFRGS). Av. Tramandaí, 976, Tramandaí, RS 95625-000 Brazil

${ }^{3}$ Museu de Zoologia da Universidade de São Paulo, Laboratório de Morfometria, Mastozoologia. Av. Nazaré, 481, Ipiranga, São Paulo, SP 04299-970 Brazil.

* Corresponding author: Larissa Rosa de Oliveira. E-mail: lari_minuano@yahoo.com.br.

Mailing address: Grupo de Estudos de Mamíferos Aquáticos do Rio Grande Sul (GEMARS), Rua Felipe Neri 382/203, Porto Alegre, RS 90440-150 Brazil.

Mobile phone number: + 55(51) 8121-1885.
} 
measurements (Crespo, 1984; Schiavini, 1992; MolinaSchiller, 2000; Molina-Schiller and Pinedo, 2004a,b) Only the study conducted by Sanfelice (2004) analyzed skull growth of otariids using traditional and geometric morphometrics.

The goal of our paper is to present a comprehensive study of sexual dimorphism in the skull of the South American fur seal, Arctocephalus australis (Zimmermann, 1783) (Carnivora: Otariidae) assessed by both traditional and geometric morphometrics methods. These approaches can be considered complementary, since traditional morphometrics analyses are necessary for comparisons with results described for related species in the literature, while the geometric morphometrics approach can be considered a more complete methodology to study size and shape differences, especially due to the representation of shape changes through diagrams (Marcus et al., 1993).

\section{Materials and Methods}

\section{Samples}

We examined skulls of 386 adult specimens of Arctocephalus australis deposited in 18 institutions and museums between 1947 and 2000, representing the most important breeding colonies of the species. We selected for this analysis two localities with representative samples for both sexes (see Appendix I), as follows: Uruguay (134 $\sigma^{\prime \prime}$ and 49 ㅇ, including specimens collected on the Brazilian coast, which according to morphological and molecular data (Oliveira, 2004) belong to the Uruguayan population) and Peru (101 6 and 102 우). Relative age categories were assigned on the basis of condylo-basal length and degree of suture obliteration (Drehmer and Ferigolo, 1997): specimens were considered adults when condylobasal length was $\geq 200 \mathrm{~mm}$ and the basioccipito-basisphenoid suture was totally fused and closed.

\section{Data analysis}

We employed geometric morphometrics (see Bookstein, 1984, 1989, 1991; Marcus et al., 1993; Rohlf and Marcus, 1993; Monteiro-Filho et al., 2002) to visualize as well as to test differences in size and shape between males and females. We also used traditional (linear) morphometrics (Marcus, 1990) to compare our results with the ones described for pinnipeds in the literature.

\section{Traditional morphometrics}

We took 15 measurements from 386 skulls of adult specimens (235 $\sigma^{\prime \prime}$ and 151 우) using a 300mm digital caliper connected to a portable computer. Measurements were based on those taken for pinnipeds by different authors (Sivertsen, 1954; Reppenning et al., 1971; Kerley and Robinson, 1987; Drehmer and Ferigolo, 1997; Oliveira et al., 1999), and are represented in Figure 1.
We employed univariate analysis (Student test) to verify the existence of significant differences between sexes within each population, and tested for the effects of population, sex and interaction between these factors with a two-way analysis of variance (ANOVA) for each individual measurement. We carried out a Principal Component Analysis (PCA) over the variance-covariance matrix of the logarithms of all measurements, to explore multivariate differences between sexes and populations (Neff and Marcus, 1980). Statistical analyses of the traditional morphometrics were performed with the programs SAS 8.02 (SAS Institute Inc., Carry, NC), SPSS 8.0 SPSS for Windows, Chicago, IL) and Systat 10 (Systat Software Inc., Point Richmond, CA).

\section{Geometric morphometrics}

For this kind of analysis it is necessary to use specimens with whole and unbroken skulls, so that all landmarks can be digitized in each image. Therefore we took 978 images from 346 skulls in dorsal (165 $\sigma^{\prime \prime}$ and 136 우), ventral (209 $\sigma^{\prime \prime}$ and 138 우), and lateral (192 $0^{\prime \prime}$ and 138 우) views, using a Pixera digital video camera connected to a portable computer with an 8$48 \mathrm{~mm}$ lens positioned parallel to the molar series in the dorsal and ventral views, and to the sagittal plane in the lateral view. The standard resolution of all images was $800 \times 600$ pixels, and always included a scale. All images were saved on jpeg format. Fifty-four anatomical landmarks (Figure 1), assumed to be morphologically and topologically equivalent in all specimens, were selected to describe the variation in skull shape, and were digitized using the software TpsDig 1.32 (Rohlf, 2003).

Landmarks were defined as follows:

Dorsal view (Figure 1A): (1) intersection between the posterior-most point on the sagittal crest and the sagittal extremity of the external nuchal crest; (2) rostral tip; (3) tip of the supraorbital process; (4) frontal-nasal suture; (5) interorbital constriction; (6) external-most point on the curve of the left side of the rostrum (canine alveolus); (7) left posterior-most point on the nuchal crest; (8) intersection between the jugal and squamosal bones; (9) post-orbital constriction; (10) external-most point on the curve of the left side of the calvaria; (11) external-most point of the jugal-maxillary suture; (12) lower-most point on the occipital crest (=occipital end); (13) anterior-most point on left nasal bone; (14) external-most point of the left mastoid process; (15) posterior-most point on left nasal bone; (16) pre-orbital process and (17) inner-most point on the internal squamosal curve.

Ventral view (Figure 1B): (18) rostral tip; (19) posterior-most point on the curve of the occipital condyle; (20) point in the middle of incisive foramina; (21) maxilla-palatine suture; (22) rear-most point of palatines; (23) external-most point on the curve of upper right canine alveolus; (24) point between the third and fourth upper right alveoli; (25) point 
of maximum curvature of the right jugal; (26) posterior edge of the sixth upper right alveolus; (27) intersection between the posterior-most point of the squamosal zygomatic process and jugal; (28) anterior-most point of the mastoid; (29) posterior-most point of the mastoid (limit between the mastoid and exoccipital); (30) carotidal posterior canal; (31) anterior edge of foramen magnum; (32) inferior tip of the hamular process of the pterygoid; (33) external-most point on the curve of right glenoid fossa; (34) interior limit of the anterior part of right glenoid fossa; (35) auditory canal; (36) middle of anterior edge of the medium lacerated foramen (=carotidal internal foramen); (37) maximum curvature of the calvaria and (38) hypoglossal foramen.
Lateral view (Figure 1C): (39) rostral tip; (40) posteriormost point of occipital condyle; (41) pre-orbital process; (42) inferior tip of the zygomatic-squamosal process; (43) superior tip of the zygomatic-squamosal process; (44) inferior tip of the mastoid; (45) nasal process of the pre-maxilla bone; (46) maxillaris foramen; (47) posterior-most point of the sagittal crest; (48) inferior tip of the hamular process of the pterygoid; (49) perpendicular line to the supra-orbital process; (50) supra-orbital process; (51) auditory canal; (52) inferior tip of the ventral nuchal crest; (53) posterior border of the glenoid fossa and (54) inferior border of the upper left canine alveolus.

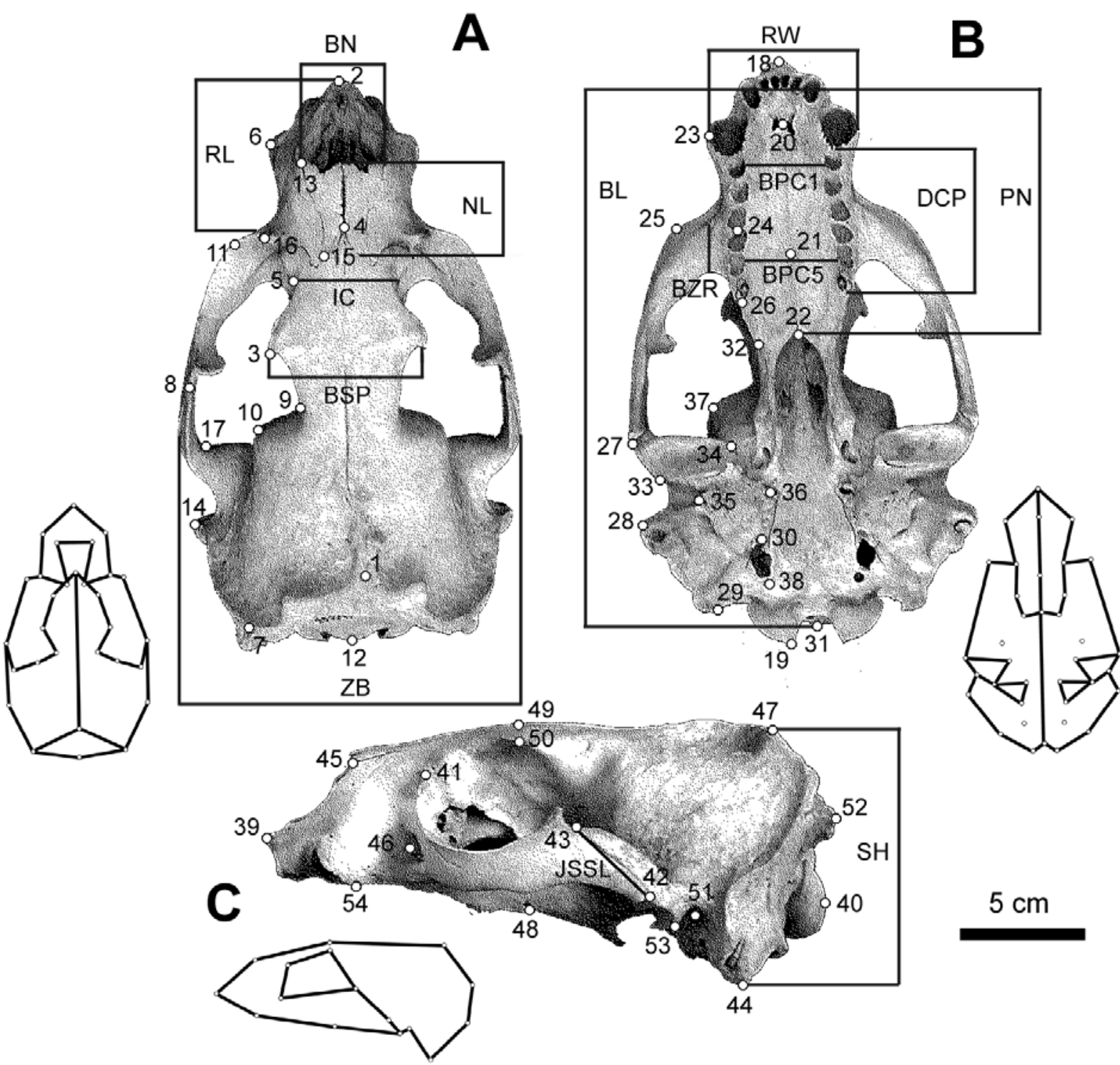

Figure 1. Numbered landmarks and linear measurements for each view: (A) dorsal, (B) ventral and (C) lateral views of the skull of Arctocephalus australis. (BL) Basal length, from incisive alveolus to foramen magnum; (BN) breadth of nasals; (BPC1) breadth of palate between first post canines; (BPC5) breadth of palate between fifth post canines; (BSP) greatest breadth at supraorbital processes; (BZR) breadth of zygomatic root of maxilla; (DCP) distance behind border of canines, from posterior margin of canines alveolus to posterior margin of right post canine 6 alveolus; (IC) interorbital constriction; (JSSL) length of jugal-squamosal suture; (NL) greatest length of nasals; (PN) palatal notch, from anterior point of palatal notch to posterior edge of central incisor alveoli; (RL) rostral length; (RW) greatest rostral width; (SH) skull height, from the occipital crest on dorsal midline to the tympanic bulla; (ZB) widest zygomatic breadth from posterior margin of squamosals. 
To avoid inflation of degrees of freedom related to the two bilaterally symmetrical views (dorsal and ventral), landmarks were digitized in half of the skull and all the analysis was performed using this configuration. For the graphical representations, we duplicated the skull coordinates along the sagittal line using the software GRFND (Slice, 1994), following the steps described in Hingst-Zaher et al. (2000).

The coordinates produced by TpsDig (Rohlf, 2003) from the images (originally recorded as pixels) were converted in millimeters by the multiplication of the established conversion factor pixel/mm of each image using the included scale in the image, and then saved in $n t$ s format. Centroid size was calculated using the software TPS Regr 1.25 (Rohlf, 2000) for the duplicated skulls, and used as a size variable independent of shape (Bookstein, 1991). Mean centroid sizes within sexes for each population were compared with analysis of two-way ANOVA.

In order to compare shape, the coordinates for each specimen in this study were scales, aligned and transformed by General Procrustes Alignment (GPA) using the software TpsRelW 1.25 (Rohlf, 2002) with the options $\alpha=0$, projection orthogonal and include uniform component. The GPA method computes a consensus configuration (least-squares Procrustes average configuration) based on the landmark coordinates of all specimens (see Bookstein, 1991, for methodological details). Shape differences between the consensus landmark configuration and each individual specimen were obtained and used to compute a matrix of partial warp scores. Relative warp scores were computed over the covariance matrix of the partial warp scores, therefore being analogous to PCA in the sense that they describe the axes of greater variation in shape for all of the analyzed specimens. The $\alpha$ parameter was set to zero to give the same weight to partial warps in smaller and greater scales (Rohlf, 1993). The partial warps matrix, including the uniform component, was used in a Canonical Variates Analysis (CVA), to describe differences between the populations and in order to confirm patterns previously suggested by the relative warps scores. We calculated the Mahalanobis distances (D2) from canonical variates scores between sexes and populations. In addition, we used the average shape for each sex and population to generate thin-platespline diagrams representing the deformation of different pairs of configurations using the software Morpheus et al. (Slice, 1999).

We compared size within sexes and between populations using two-way ANOVA, and examined the relationship between size and shape by plotting centroid size versus the first and second relative warps. All statistical analyses of the geometric morfometrics were performed using SAS 8.02 (SAS Institute Inc., Carry, NC), SPSS 8.0 (SPSS for Windows, Chicago, IL) and Systat 10 (Systat Software Inc., Point Richmond, CA).

\section{Results}

\section{Traditional Morphometrics}

Results of the $t$-test indicated a pronounced sexual dimorphism in adults of both populations from Uruguay and Peru (Tables 1 and 2), with males being larger than females. Results of the two-way ANOVA indicated that all measurements were statistically different between sexes $(P<0.001)$. Only two measurements did not present differences between populations (interorbital constriction and greatest breadth at supraorbital processes) and three measurements (breadth of palate between first post canines, greatest breadth at supraorbital processes and breadth of nasals) showed significant interaction between sex and population pointing to the existence of different degrees of sexual dimorphism in the populations.

In the PCA the first principal component (PC1) explained $70.31 \%$ and the second (PC2) $10.26 \%$ of the total observed variability (Figure 2). The measurements with highest loadings on PC1 were: greatest rostral width, breadth of palate between first post canines, breadth of nasals and breadth of zygomatic root of maxilla, and the three first were related to rostral width, indicating that these differences in rostral region have an important role in the skull size sexual dimorphism of the species. All loadings for the eigenvectors of the PC1 were positive, suggesting that they are all correlated with size (Figure 2).

Scores of the specimens in the first two components (Figure 2) delineated two groups based on sex. Males and females were separated from each other mainly along the first component axis, suggesting that sexual dimorphism is strongly related to size, with males being larger than females. The PCA also indicates a separation between Uruguayan and Peruvian populations along the second principal component axis, pointing to the existence of geographic differences in size and shape between these two populations. All skull means from Peru are larger than those from Uruguay (Tables 1 and 2). These results show that most of the differences between sexes are expressed in the overall size of cranial characteristics with shape expressing much less variation (Neff and Marcus, 1980).

\section{Geometric morphometrics}

Size: Results of $t$-tests showed significant differences in centroid size between sexes within both populations for all studied views (Table 3), with males being larger than females. Peruvian specimens from both sexes are larger than Uruguayan ones. The two-way ANOVA showed significant effects of sex and population (Peru and Uruguay) for all views (Sex - dorsal: $F=504.61, P<0.0001$; ventral: $F=621.73, P<0.0001$; lateral: $F=651.91, P<0.0001$. Population - dorsal: $F=27.38, P<0.0001$; ventral: $F=59.25$, $P<0.0001$; lateral: $F=58.86, P<0.0001)$, but no significant effects of interaction between sex and population.

Shape: For the dorsal view, 21 relative warps represent more than $95 \%$ of the total shape variation $(32.62 \%$ in the first and $12.07 \%$ in the second relative warp). For the 
ventral view, 26 relative warps represent more than 95\% (18.89\% in the first and $13.62 \%$ for the second relative warp). For the lateral view, $95 \%$ of the variation is summarized by 19 relative warps $(24.13 \%$ for the first and $13.15 \%$ for the second relative warp). The relationship between the first relative warp and centroid size indicates that sexual dimorphism is strongly related to size just for the ventral view $(r=0.83, p<0.001)$. Shape differences related to the first relative warp in the ventral view are concentrated in the rostral region, being larger in males than in females (Figure 3).

The first two canonical axes in the CVA explained $97.87 \%$ of the observed variation for dorsal view, $96.52 \%$ for ventral and $95.34 \%$ for lateral view. Figure 4 presents shape changes associated with the canonical variates scores for dorsal and ventral views of the skulls. For the dorsal view (Figure 4A), males and females show a separation along the first axis, with male skulls presenting a rostral region and supra-orbital process broader than females. Females have in general a thinner and longer skull in the rostral region compared to males, while the latter present skulls compressed in the braincase. There is also a geographic separation between Peruvian and Uruguayan specimens along the second axis (Figure 4A), with the Peruvian population presenting a compressed braincase and a rostral region broader than the Uruguayan population. For the ventral view (Figure 4B), there is a separation between the Uruguayan males and the other three groups along the first axis. Skull shapes associated with the ventral scores range from a thinner to broader rostrum and from a normal to an accentuated jugal angle (Figure 4B). The Mahalanobis D2 values are given in Table 4, and Fvalues were significant $(P<0.001)$ for each paired comparison. There are significant differences between the four groups in the three views (dorsal: Wilks' lambda $=$ 0.0425 , d.f. $=87 / 805.76, P<0.0001$; ventral: Wilks' lambda $=$ 0.0327, d.f. $=111 / 923.41, P<0.0001$ and lateral: Wilks' lambda $=0.0769$, d.f. $=81 / 898.14, P<0.0001)$. In general, females belonging to different populations are closer to one another than males from different populations, suggesting that males are more variable in skull shape than females.

The diagrams with average configuration of skull shape of males and females from Uruguayan and Peruvian populations are presented in Figure 5. Sexual dimorphism in shape is more pronounced for the dorsal and ventral views, mainly in the anterior region of the skull. The dorsal view was the most informative, with males showing more developed rostrum and supra-orbital process than females, especially in the Uruguayan population, where the differences between sexes were more pronounced in the rostral region. These results agree with the ones from traditional morphometrics analyses, in which the two-way ANOVA suggested different degrees of sexual dimorphism between populations, mainly related to linear measurements of this particular skull region. For the ventral view, we observed that the width of rostrum, palate and skull (mastoid breadth) of males from both populations were larger than the same region of the females. In the lateral view there was little difference in skull shape between the sexes, mainly related to the end of the sagittal crest and skull height.

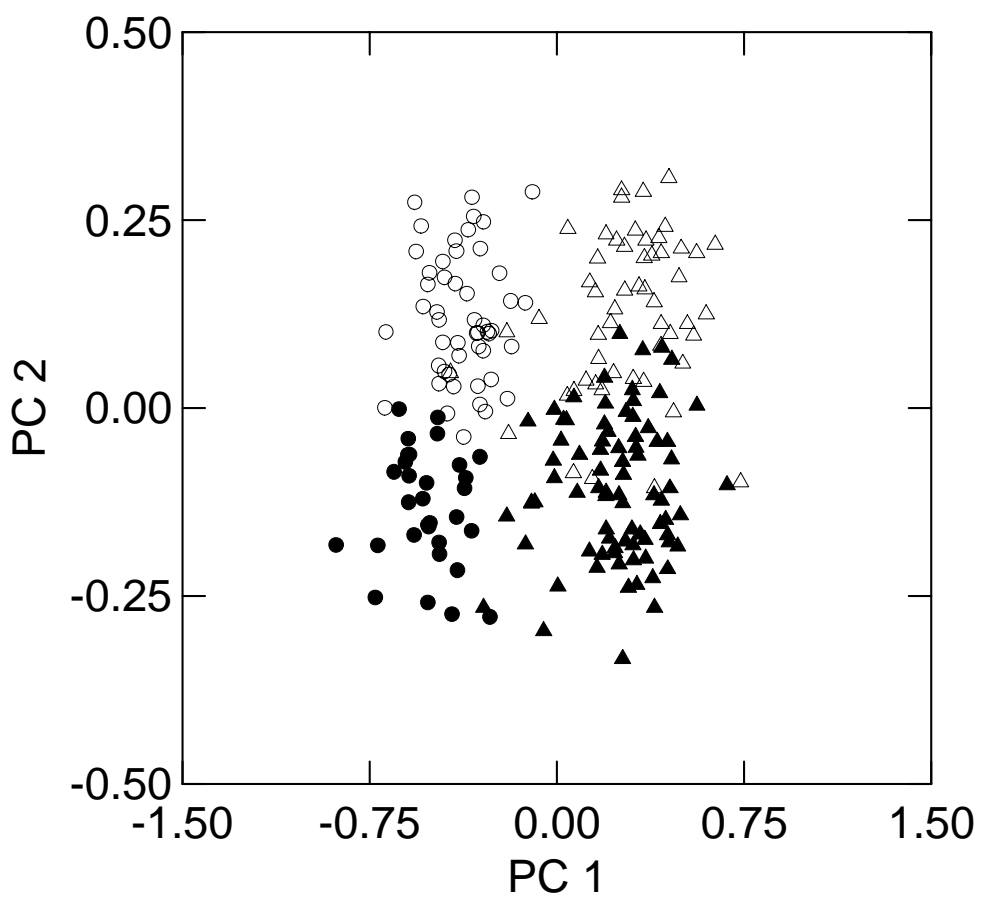

Figure 2. Scores of the specimens of A. australis in the first two axes of the principal component analysis (PCA). ( $\mathbf{\Delta}$ ) males from Uruguay; $(\triangle)$ males from Peru; $(\bullet)$ females from Uruguay; (O) females from Peru. 
Table 1. Mean and standard deviation of the 15 skull measurements ( $\mathrm{mm}$ ) from Arctocephalus australis skulls belonging to the specimens from Uruguay, and results of the $t$-test for sexual dimorphism (see figure 1 for a description of the measurements).

\begin{tabular}{|c|c|c|c|c|c|c|c|}
\hline \multirow[b]{2}{*}{ MEASUREMENTS } & \multicolumn{3}{|c|}{$\sigma^{\prime \prime}$} & \multicolumn{2}{|l|}{ 우 } & \multirow[b]{2}{*}{ d.f. } & \multirow[b]{2}{*}{$P$} \\
\hline & $\mathrm{n}$ & MEAN (SD) & $\mathrm{n}$ & MEAN (SD) & $t$ & & \\
\hline $\mathrm{BL}$ & 131 & $207.15(9.03)$ & 49 & $180.73(5.39)$ & 19.23 & 178 & 0.004 \\
\hline DCP & 125 & 56.59 (2.95) & 48 & $52.21(2.32)$ & 9.23 & 171 & 0.168 \\
\hline $\mathrm{ZB}$ & 129 & $134.89(7.52)$ & 48 & $114.24(4.24)$ & 17.96 & 175 & 0.0001 \\
\hline RW & 118 & $49.91(4.07)$ & 45 & 35.17 (1.85) & 23.38 & 161 & 0.0001 \\
\hline $\mathrm{SH}$ & 134 & $95.49(5.22)$ & 49 & 81.25 (2.77) & 18.16 & 181 & 0.0001 \\
\hline $\mathrm{PN}$ & 130 & $94.87(5.61)$ & 49 & 81.53 (3.84) & 15.34 & 177 & 0.007 \\
\hline BPC1 & 130 & $25.36(2.69)$ & 49 & $18.66(1.46)$ & 16.51 & 177 & 0.0001 \\
\hline BPC5 & 127 & 33.59 (2.84) & 47 & $28.02(2.00)$ & 12.35 & 172 & 0.073 \\
\hline NL & 107 & $36.34(3.03)$ & 37 & $31.32(2.48)$ & 9.07 & 142 & 0.039 \\
\hline IC & 133 & $33.86(3.42)$ & 49 & 24.66 (1.99) & 17.72 & 180 & 0.0001 \\
\hline BSP & 126 & $52.29(5.28)$ & 48 & 40.13 (2.93) & 15.08 & 172 & 0.0001 \\
\hline RL & 129 & 68.58 (3.57) & 49 & 58.59 (2.59) & 17.86 & 176 & 0.027 \\
\hline $\mathrm{BN}$ & 99 & 31.45 (2.97) & 35 & 24.18 (1.39) & 13.92 & 132 & 0.0001 \\
\hline BZR & 132 & $16.13(1.85)$ & 49 & $12.64(1.28)$ & 12.17 & 179 & 0.004 \\
\hline JSSL & 128 & $36.34(4.01)$ & 48 & 29.93 (2.39) & 10.39 & 174 & 0.002 \\
\hline
\end{tabular}

Table 2. Mean and standard deviation of the 15 skull measurements ( $\mathrm{mm}$ ) from Arctocephalus australis skulls belonging to the specimens from Peru, and results of the $t$-test for sexual dimorphism (see figure 1 for a description of the measurements).

\begin{tabular}{|c|c|c|c|c|c|c|c|}
\hline \multirow[b]{2}{*}{ MEASUREMENTS } & \multicolumn{3}{|c|}{$\sigma^{\prime}$} & \multicolumn{2}{|l|}{ 오 } & \multirow[b]{2}{*}{ d.f. } & \multirow[b]{2}{*}{$P$} \\
\hline & $\mathrm{n}$ & MEAN (SD) & $\mathrm{n}$ & MEAN (SD) & $t$ & & \\
\hline $\mathrm{BL}$ & 99 & $213.53(8.50)$ & 102 & $187.56(5.14)$ & 26.30 & 199 & 0.0001 \\
\hline $\mathrm{DCP}$ & 93 & $60.36(2.85)$ & 100 & $55.22(2.48)$ & 13.43 & 191 & 0.120 \\
\hline $\mathrm{ZB}$ & 101 & $140.26(7.97)$ & 101 & $121.30(4.02)$ & 21.35 & 200 & 0.0001 \\
\hline RW & 85 & $51.70(4.28)$ & 90 & $38.25(2.31)$ & 26.08 & 173 & 0.0001 \\
\hline $\mathrm{SH}$ & 101 & $98.30(5.44)$ & 102 & 85.54 (2.79) & 21.06 & 201 & 0.0001 \\
\hline $\mathrm{PN}$ & 101 & $98.23(6.74)$ & 100 & $86.04(4.48)$ & 15.09 & 199 & 0.0001 \\
\hline BPC1 & 100 & $25.47(2.76)$ & 102 & $19.80(1.42)$ & 18.38 & 200 & 0.0001 \\
\hline BPC5 & 101 & $37.76(3.15)$ & 100 & 31.67 (2.14) & 16.01 & 199 & 0.0001 \\
\hline NL & 67 & 35.33 (3.59) & 68 & $29.66(2.65)$ & 10.46 & 133 & 0.025 \\
\hline IC & 100 & $33.68(2.86)$ & 102 & 25.37 (1.99) & 23.96 & 200 & 0.040 \\
\hline BSP & 87 & $50.69(4.56)$ & 85 & 40.74 (3.88) & 15.39 & 170 & 0.165 \\
\hline RL & 100 & $66.88(3.53)$ & 102 & $58.14(2.48)$ & 20.38 & 200 & 0.021 \\
\hline $\mathrm{BN}$ & 66 & $27.63(2.20)$ & 64 & 22.09 (1.73) & 15.95 & 128 & 0.313 \\
\hline BZR & 100 & $17.91(1.96)$ & 102 & $14.30(1.41)$ & 15.02 & 200 & 0.002 \\
\hline JSSL & 95 & $40.81(4.30)$ & 95 & $34.90(2.60)$ & 11.46 & 188 & 0.0001 \\
\hline
\end{tabular}

Table 3. Mean and standard deviation for skull size (centroid size) in millimetres of both sexes and populations of Uruguay and Peru of Arctocephalus australis, for dorsal, ventral and lateral views.

\begin{tabular}{|c|c|c|c|c|c|c|c|c|c|c|}
\hline \multirow[b]{2}{*}{ VIEW } & \multirow[b]{2}{*}{ POPULATION } & \multicolumn{3}{|c|}{$\sigma^{\prime}$} & \multicolumn{3}{|c|}{ 오 } & \multirow[b]{2}{*}{$t$} & \multirow[b]{2}{*}{ d.f. } & \multirow[b]{2}{*}{$P$} \\
\hline & & $\mathrm{n}$ & MEAN & (SD) & $\mathrm{n}$ & MEAN & (SD) & & & \\
\hline \multirow[t]{2}{*}{ Dorsal } & Uruguay & 103 & 261.81 & 15.45 & 42 & 227.21 & 7.74 & 13.81 & 143 & 0.001 \\
\hline & Peru & 62 & 268.64 & 13.87 & 94 & 236.03 & 7.73 & 18.80 & 154 & 0.001 \\
\hline \multirow[t]{2}{*}{ Ventral } & Uruguay & 120 & 305.33 & 16.39 & 43 & 266.59 & 8.97 & 14.71 & 161 & 0.0001 \\
\hline & Peru & 89 & 317.56 & 14.98 & 95 & 278.47 & 8.96 & 21.64 & 182 & 0.001 \\
\hline \multirow[t]{2}{*}{ Lateral } & Uruguay & 105 & 291.22 & 15.87 & 40 & 251.03 & 8.28 & 15.23 & 143 & 0.0001 \\
\hline & Peru & 87 & 301 & 13.46 & 98 & 264.34 & 9.13 & 21.88 & 183 & 0.001 \\
\hline
\end{tabular}




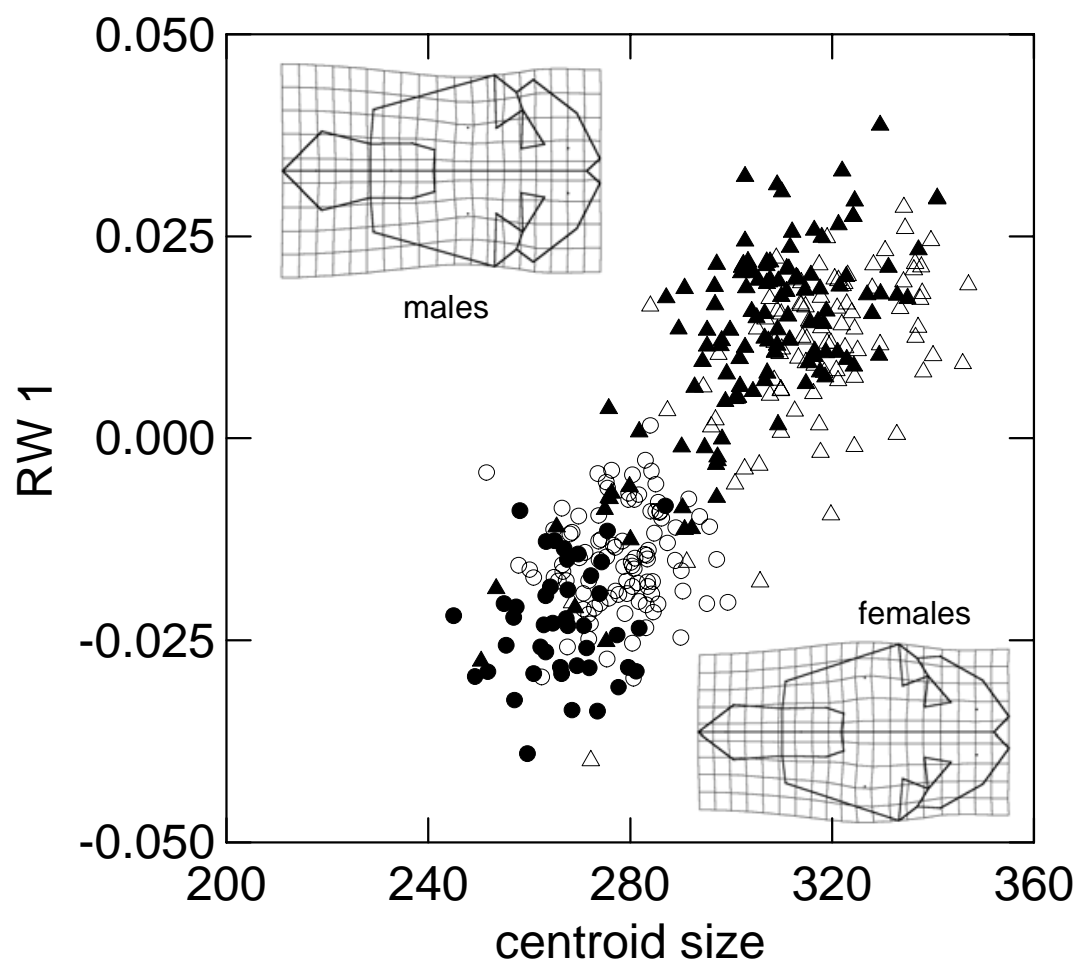

Figure 3. Regression of size (centroid size) over the first relative warp (RW1) for the ventral view of skulls of males from Uruguay ( $\mathbf{\Delta})$ and Peru $(\triangle)$ and females from Uruguay $(\bullet)$ and Peru $(\bigcirc)$. The diagrams represent the extremes of skull shape associated with bigger (upper left) and smaller (down right) skulls.

Table 4. Mahalanobis D2 (above diagonal) and their F-values (below) computed among males and females from Uruguayan and Peruvian populations of Arctocephalus australis, based on partial warp scores, for dorsal, ventral and lateral views. All distances were significant to $P<0.001$.

\begin{tabular}{|c|c|c|c|c|}
\hline & \multicolumn{2}{|c|}{ URUGUAY } & \multicolumn{2}{|c|}{ PERU } \\
\hline Dorsal View & 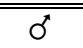 & 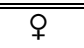 & $\overline{\bar{q}}$ & $\sigma^{\prime \prime}$ \\
\hline \multicolumn{5}{|l|}{ Uruguay } \\
\hline $0^{\prime \prime}$ & 0 & 24.35 & 46.07 & 12.62 \\
\hline 우 & 26.13 & 0 & 8.07 & 21.43 \\
\hline \multicolumn{5}{|l|}{ Peru } \\
\hline 우 & 30.02 & 8.90 & 0 & 21.48 \\
\hline$\sigma^{\prime \prime}$ & 10.44 & 27.40 & 18.41 & 0 \\
\hline \multicolumn{5}{|l|}{ Ventral View } \\
\hline \multicolumn{5}{|l|}{ Uruguay } \\
\hline$\sigma^{\circ}$ & 0 & 15.86 & 43.70 & 22.65 \\
\hline 오 & 20.71 & 0 & 12.32 & 21.50 \\
\hline \multicolumn{5}{|l|}{ Peru } \\
\hline 우 & 34.06 & 17.20 & 0 & 16.00 \\
\hline $0^{\prime \prime}$ & 18.20 & 30.54 & 14.38 & 0 \\
\hline \multicolumn{5}{|l|}{ Lateral View } \\
\hline \multicolumn{5}{|l|}{ Uruguay } \\
\hline $0^{\prime \prime}$ & 0 & 11.26 & 32.34 & 20.76 \\
\hline 오 & 11.40 & 0 & 10.88 & 19.48 \\
\hline \multicolumn{5}{|l|}{ Peru } \\
\hline 오 & 18.72 & 11.24 & 0 & 13.78 \\
\hline $0^{\prime \prime}$ & 12.80 & 20.86 & 8.77 & 0 \\
\hline
\end{tabular}


A

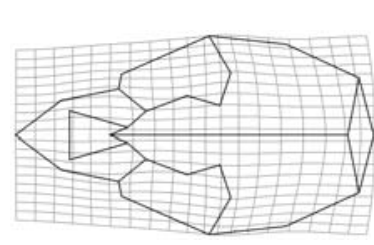

Uruguayan specimens

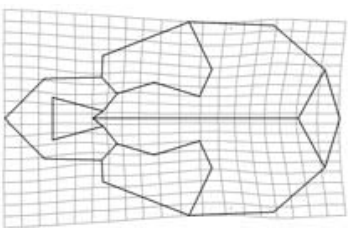

Peruvian specimens
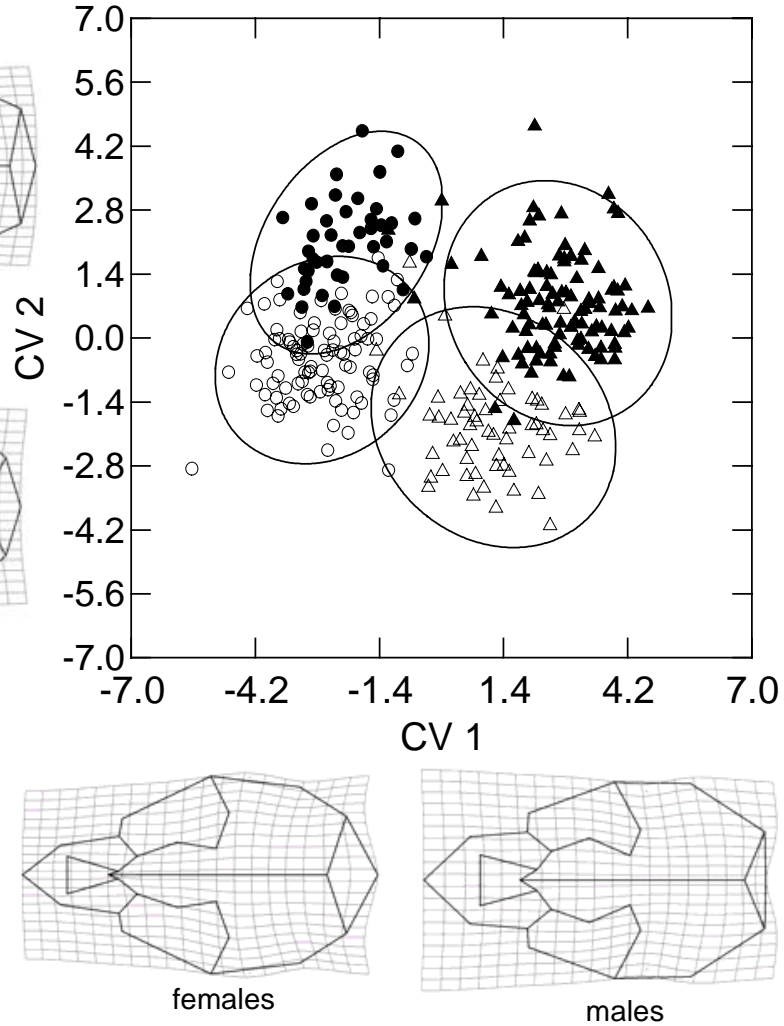

B
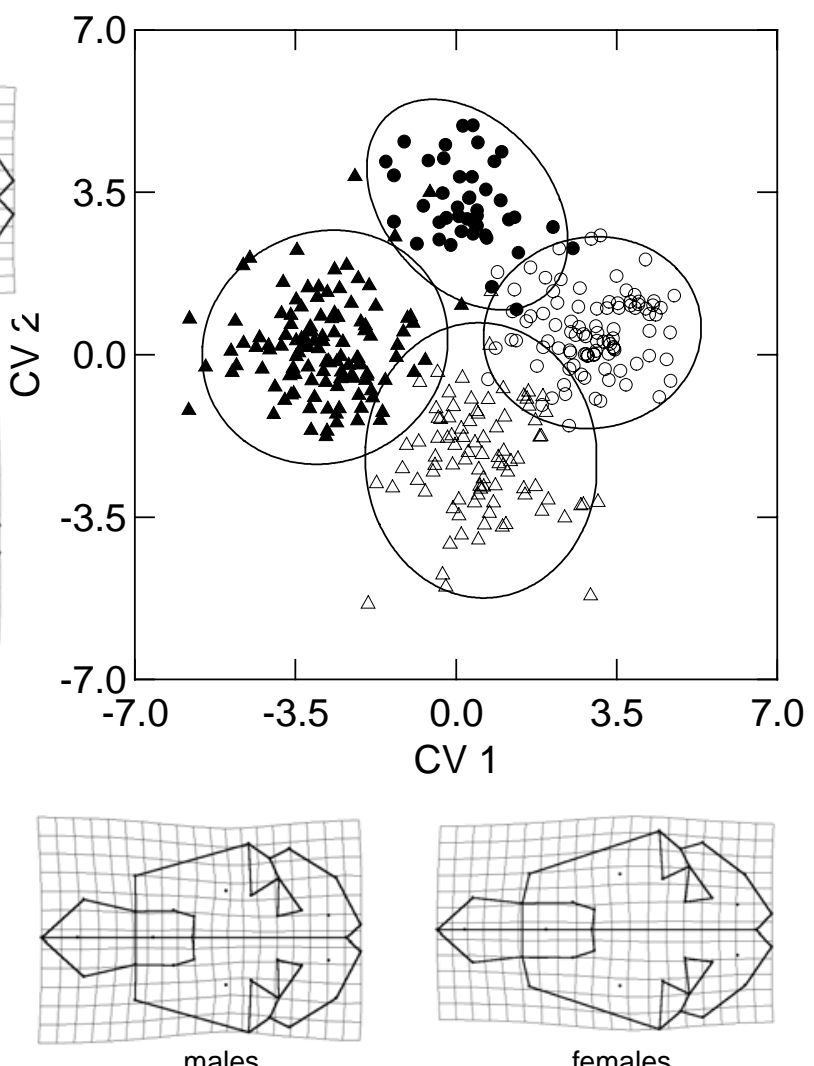

females

Figure 4. Canonical variates analysis plot based on scores of dorsal and ventral views: (A) dorsal view, (B) ventral View. Diagrams represent extreme skull shapes resulting from regression of shape coordinates over canonical scores. $(\boldsymbol{\Delta})$ males from Uruguay; $(\triangle)$ males from Peru; (•) females from Uruguay; (O) females from Peru. 


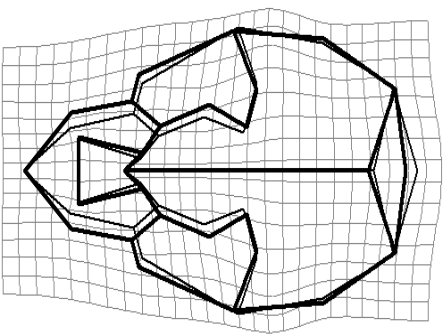

A

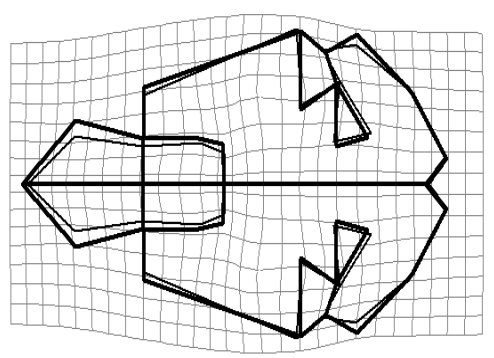

C

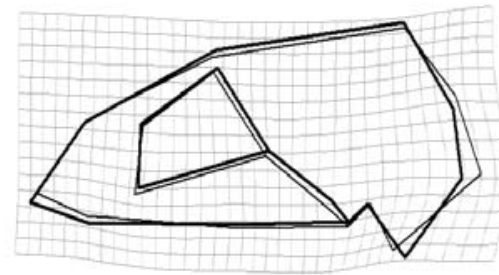

E

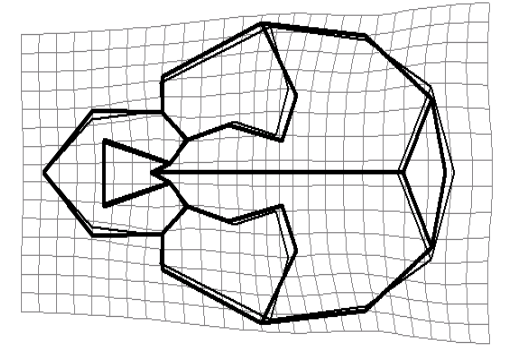

B

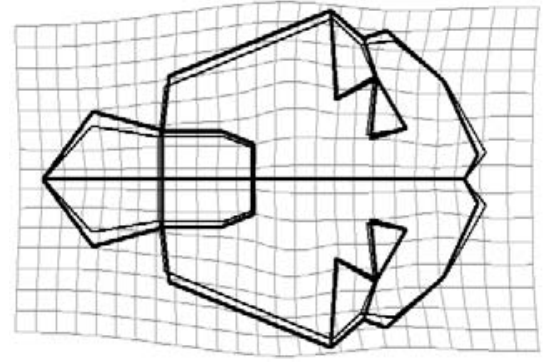

D

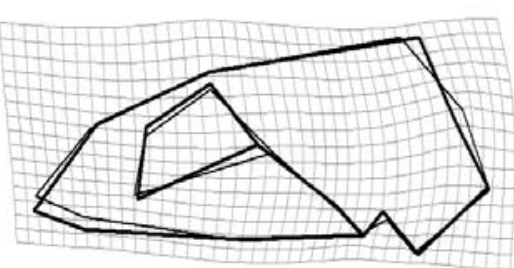

$\mathbf{F}$

Figure 5. Average configuration of males and females from Uruguay and Peru: (A) Uruguayan population in dorsal view: $\sigma^{\prime \prime}$ (thick line) $(n=103)$, ㅇ (thin lines) $(n=42) ;(B)$ Peruvian population in dorsal view: $\sigma^{\prime}$ (thick line) $(n=62)$, ㅇ (thin lines) ( $\left.n=94\right)$; (C) Uruguayan population in ventral view: $0^{\prime \prime}$ (thick line) $(n=120)$, ㅇ (thin lines) $(n=43) ;(D)$ Peruvian population in ventral view: $O^{\prime \prime}($ thick line) $(n=90)$, + (thin lines) $(n=95) ;(E)$ Uruguayan population in lateral view: $\sigma^{\prime \prime}$ (thick line) $(n=105),+$ (thin lines) $(n=40) ;(F)$ Peruvian population in lateral view: $\sigma^{\prime \prime}$ (thick line) $(n=87)$, + (thin lines) $(n=98)$.

\section{Discussion}

Traditional morphometrics indicated the existence of pronounced sexual dimorphism in Arctocephalus australis related to skull size, with males being larger than females. Geometric morphometrics analysis detected skull shape differences especially in the dorsal and ventral views and concentrated in the rostral region. Sexual dimorphism has different degrees of intensity in the two studied populations. Sexual dimorphism in the Uruguayan population was evident not just in skull size but also in skull shape, while the Peruvian population presented sexual dimorphism mainly related to skull size. A clear pattern of separation between populations was detected by traditional and geometric morphometrics methods, suggesting the existence of geographic variation in $A$. australis. The pronounced sexual dimorphism found in skulls of $A$. australis, with males being larger than females, is a regular phenomenon observed in body size in all pinniped species presenting terrestrial and highly polygynous mating systems, such as otariids and some phocids (e.g. elephant seals, Mirounga spp., and the grey seal, Halichoerus grypus), related to sexual selection (Campagna, 2002; Ralls and Mesnick, 2002).

Arctocephalus australis is one of 18 species of pinnipeds which presents terrestrial reproduction, high level of polygyny and accentuated sexual dimorphism and forms moderate to large breeding colonies. The largest breeding colony is at Isla de Lobos in Uruguay with more than 150,000 specimens (Vaz-Ferreira, 1982; Riedman, 1990; Ximenez and Langguth, 2002). Within these colonies, there are dense groups of females (harems) where just a small number of males will mate with many females. This results in an intense competition among males for access to their mates (Bartholomew, 1970; Stirling, 1983). Sexual selection can favor the development of secondary sexual traits, several of which may represent some added function in a competition context between males (Campagna, 2002). As secondary sexual traits of phocid males we can mention marked nasal features, such as the enlarged nose (proboscis) in elephant seals, a broad and elongated snout in grey seals, or an external bright 
red nasal sac in hooded seals (Cystophora cristata). In adult male otariids, besides their larger canine teeth and broader rostrum than females (Crespo, 1984), their head, neck and chest tend to be covered by longer, rougher hairs, giving the impression of a mane (particularly conspicuous in the South American sea lion, Otaria byronia $=0$. flavescens). These hairs protect the internal organs from possible bites during fights (Riedman, 1990; Campagna, 2002). In general, the development of all mentioned traits, as well as size dimorphism, is related to male agonistic encounters in polygynous mating systems, especially those involving resource defense (territorial) and female defense. The establishment and defense of both types involve demonstrations of strength and dominance, which include vocal displays, stereotyped postures and movements, and fights, with death occurring on rare occasions (Riedman, 1990; Campagna, 2002). The selective pressures of sexual selection in polygynous pinnipeds explain the skull differences between male and female $A$. australis found in the present study, based on the fact that this phenomenon can favor the development of traits that improve fighting skills among males, such as huge canine teeth and broader rostrum and mastoid, also general increment of body size (Campagna, 2002; Mesnick and Ralls, 2002). In this sense, the male skull is co-determined by size of cranial muscles; hence the robustness of the attachments associated with closure of the lower jaw (musculi masseter, temporalis and digastricus), as well as the muscles of the neck that attach to the rear of the skull (sternocephalicus, longissimus capitis, sternothyroideus) (Brunner, 1998).

Brunner (2000), observing the age and great secondary development of some skull regions in otariids, reported that these modifications occur exactly when reaching social maturity, when males start to defend territories or reach a good hierarchical position in a colony. According to this author, these skull changes are mainly associated with canine teeth width, rostral width, and skull width at the level of the pre- and supra-orbital process, giving an increment in strength and bite capacity. Likewise, changes in the height of occipital and sagittal crests of otariids will enlarge their robust head. These parts of the skull are broadly used during physical confrontations between males in territorial disputes.

In addition to sexual selection, another hypothesis for sexual dimorphism is the existence of differences between life history of males and females and related to differential maternal investment. In otariids this pattern is still unclear. Studies generally seem to indicate that male pups are heavier at birth and grow slightly faster, but that they do not receive more milk than female pups. For instance, Arnould et al. (1996) showed that although male and female Antarctic seal (Arctocephalus gazella) pups received equal amounts of milk, males invested more in lean tissue growth while females accumulated greater adipose stores. Since fat and lean tissue differ in terms of density and energy content, a lighter but fatter pup may still have received the same amount of energy and material from its mother as a bigger, heavier pup. In general, the evidence for differential expenditure in the sexes seems rather tenuous (Trillmich, 1996).

The pronounced sexual dimorphism in skulls of $A$. australis described here for the populations of Uruguay and Peru corroborates previous studies (Ximenez et al., 1984; Drehmer and Ferigolo, 1996; Brunner, 2000; Molina-Schiller, 2000; Molina-Schiller and Pinedo, 2004b; Sanfelice, 2004). The allometry observed in the ventral view of males and females of $A$. australis agrees with the results found by Drehmer and Ferigolo (1996) and Molina (2000). King (1954:312) reported that this species does not show allometric cranial growth, mainly related to condylobasal length. However, the same specimens used by King (1954) were re-examined in the present study. The author perhaps did not separated males from females, nor juveniles from adult animals, which may explain discordant results.

The different degree of sexual dimorphism as found here between the two studied populations and mainly related to the rostral region, can be attributed to dissimilar diets in each locality (Majluf, 1987a, 1992; Naya et al., 2002), to reproductive strategies with different levels of polygyny, as suggested by Lindenfors (2002) and Ralls and Mesnick (2002) and/or even to nonadaptive divergence, as a result of processes such as genetic drift due to geographic isolation.

The diet of $A$. australis studied through faecal analysis in Isla de Lobos indicated that the main prey consumed in Uruguay were cephalopods and teleost fish such as weakfish (Cynoscion guatucupa), cutlassfish (Trichiurus lepturus), anchoveta (Engraulis anchoita) and anchovy (Anchoa marinii), the fish ranging in length from 5.4 to $104.8 \mathrm{~cm}$ and from 0.7 to $629.9 \mathrm{~g}$ in wet mass (Naya et al., 2002; Szteren et al., 2004). In Peru, A. australis feeds mainly on anchoveta (E. ringens) with an average length of 20cm (Majluf, 1992). The most remarkable difference in diet between the two populations was the predation on large species ( $T$. lepturus, average length $=67.9 \mathrm{~cm}$ ) by Uruguayan specimens (Naya et al., 2002). In this sense, the ingestion of larger and more robust prey by the Uruguayan population could select for more robust lower and upper jaws and, consequently, to modifications in the rostral region, one of the most evident body parts areas showing sexual dimorphism in A. australis. However, there is no information about potential differences in diet among males and females for either population. We suggest that the observed differences in the degree of sexual dimorphism may be more related to geographic differences in diet of the populations (ecosystem differences) than between sexes. An alternative hypothesis to explain the different degree of sexual dimorphism between the two studied populations is the existence of more than one polygynyc strategy in the same species. In the $A$. australis population from Uruguay, a territory system prevails with males defending tide pools in the intertidal zone, which are important thermoregulatory resource for 
females (Cappozzo et al., 19964). There, each territory is occupied by one alpha male and its harem, with 6 to 14 adult females in general (Kovacs and Lavigne, 1992; Ximenez and Langguth, 2002), whereas at Punta San Juan, on the Peruvian coast, a lekking system (Majluf, $1987 b$ ) is used by the local fur seal population. In this system, males are grouped in small territories without any important resources and receptive females regularly visit these areas. Movements of individual females are not random and they tend to shift between a few preferred rocks or resting sites, associating with several territorial males during the day. Thus, there is no stable harem structure. However, because of the females' fidelity to specific places on the beach, it is very likely that they associate with the same set of males each day. Males have to spend just a minimum effort to retrieve and copulate with the females. This absence of great effort to control females is the main contrast between defense of stable territories or defense of females and the lekking system (Boness, 1991).

Thus, in the Uruguayan population, where the polygyny strategy adopted is defense of structured and stable territories, more intense physical confrontations would be required, and sexual selection could act in favor of the enhancement of male skull traits (resulting in more robust, dimorphic skulls), more than in males in Peruvian colonies using the lekking system, where there is no stable harem structure and thus lesser fights.

More than one type of polygyny also occurs in the South American sea lion populations, as function of different ecological conditions. According to Campagna and Le Boeuf (1988), the breeding colonies of O. byronia at Punta Norte, Península Valdés, Argentina, use wide and uniform beaches without any tide pools, and thus without means to relieve heat stress. Whereas at Puerto Piramide, another beach at Península Valdés, where colonies use rocky shelves containing tide pools and boulders providing shade, heat stress is much more easily relieved. Effective thermoregulation is extremely important to the sea lions during the hot, dry breeding season. At Punta Norte males employ a strategy of herding or sequestering females (female defense). At Puerto Piramide rookery, competition for and defense of preferred territories is more intense. The male's success in mating varies more in this area: those whose territories contain the largest tide pools copulate more than those in poorer territories.

The suggestion of the relationship between different kinds of polygyny and degrees of sexual dimorphism presented by the two populations of $A$. australis is in accordance with the results of Lindenfors et al. (2002). These authors tested whether Rensch's rule (Rensch, 1950), which states that there is a tendency to increase the degree of sexual size dimorphism with body size, was valid for otariids or not. After the evaluation of harem size, weight and total length of males and females of all species of pinnipeds, they concluded that the degree of sexual dimorphism was not related to body size, but would be an answer of males to sexual selection directly related to harem size controlled by these males. In other words, the more polygynous the species, the more dimorphic in size it will be.

In summary, there exists pronounced sexual dimorphism in the skull of $A$. australis, mainly related to sexual selection. The two studied populations show different degrees of dimorphism, suggesting the existence of geographic variation in the species. The differences in adopted breeding systems, as well as in physiological and behavioral answers to oceanographic phenomena such as El Niño off Peru (Majluf et al., 1987b; Arias-Schreiber and Rivas, 1998) could be some of the causes that drive the geographic variation observed between the skulls of males and females from Uruguayan and Peruvian populations. These craniometrical differences were reported by Oliveira et al. (1999) and Brunner (2000) as intraspecific variation; however Oliveira (2004) suggested that these morphological differences associated with molecular differences and distinct breeding systems could reflect distinct evolutionary significant units (ESU - Moritz, 1994) or even different species.

\section{Acknowledgements}

Thanks to the collection managers: Paulo César SimõesLopes (LAMAQ/UFSC, Florianópolis, Brazil); Ignacio B. Moreno (GEMARS/CECLIMAR, Porto Alegre, Brazil), Mônica M. Muelbert (LMM/FURG, Rio Grande, Brazil); Cibele Andruziak (MCN/FZBRS, Porto Alegre, Brazil); Charles Potter and James Mead (NMNH, Washington DC, USA); Robert Randall (AMNH, New York, USA); Paula Jenkins, Richard Harbour and Daphne (BMNH, London, UK); Adrian Friday (MZUniversity of Cambridge, Cambridge, UK); Walter Sielfeld (UAP, Iquique, Chile); Claudio Venegas (IP, Punta Arenas, Chile); Luiz Cappozzo and Olga Vacaro (MACN «Bernardino Rivadávia», Buenos Aires, Argentina); Diego Rodriguez and Ricardo Bastida (FCN, Mar del Plata, Argentina); Natalie P. Goodal (Museo Acatushún, Ushuaia, Argentina); Ernesto Piana (CADIC, Ushuaia, Argentina); Enrique Crespo (CENPAT, Puerto Madryn, Argentina), Patricia Majluf (Proyecto Punta San Juan, Lima, Peru), Alfredo Le Bas and Mario Clara (FCN, Montevideo, Uruguay). To Diego Astua de Moraes, who prepared the figure 1 and also with Lucio Vinicius Castilho, kindly reviewed the manuscript. To Daniza Molina and Koen Van Waerebeek who provided valuable criticism to improve

\footnotetext{
${ }^{4}$ Cappozzo, H.L., Perez, F. and Batalles, L.M. (1996) Reproductive behavior of South American fur seals in Uruguay. Page 37 in Abstracts, International Symposium and workshop on Otariid reproductive strategies and conservation, 12-16 April, Washington, USA.
} 
this article. To Fundação de Amparo à Pesquisa do Estado de São Paulo (FAPESP), which provided the PhD grant to L.R.O. (FAPESP 00/00248-2, 00/01340-0) and also to Society for Marine Mammalogy (grants-in-aid program) for partially funding the museum visits. This study is part of the dissertation presented by Larissa Rosa de Oliveira, submitted in partial fulfillment for a PhD degree in Biology (Genetics) at Universidade de São Paulo, Brazil.

\section{References}

Alexander, R. D., Hoogland, J. L., Howard, R. D., Nooman, K. M. AND SHerman, P. W. (1979) Sexual dimorphism and breeding system in pinnipeds, ungulates, primates and humans. Pages 402-435 in Chagnon, N. A. and Irons, W. D. (Eds) Evolutionary Biology and Human Social Behaviour: An Anthropological Perspective. Duxbury Press, North Scituate, Massachusetts.

Arias-Schreiber, M. and Rivas, C. (1998) Distribuición, tamaño y estructura de las poblaciones de lobos marinos Arctocephalus australis y Otaria byronia en el litoral Peruano, en Noviembre 1996 y Marzo 1997. Informe Progresivo del Instituto del Mar del Perú 73: 17-32.

Arnould, J. P. Y., Boyd, I. L And Socha, D. G. (1996) Milk consumption and growth efficiency in Antarctic fur seal (Arctocephalus gazella) pups. Canadian Journal of Zoology 74: 254-266.

Bartholomew, G. A. (1970) A model for the evolution of pinniped polygyny. Evolution 24: 546-559.

Berta, A. And Sumich, J. L. (1999) Marine Mammals, Evolutionary Biology. Academic Press, San Diego, California.

Boness, D. J. (1991) Determinants of mating systems in the Otariidae (Pinnipedia). Pages 1-44 in Renouf, D. (Ed) The behaviour of pinnipeds. Chapman and Hall, London, United Kingdom.

BooKsteIn, F. L. (1984) A statistical method for biological shape comparisons. Journal of Theoretical Biology 107: 475-520.

Bookstein, F. L. (1989) Size and shape: a comment on semantics. Systematic Zoology 38: 173-180.

BooKsteIN, F. L. (1991) Morphometric Tools for Landmark Data: Geometry and Biology. Cambridge University Press, New York.

BRUNNER, S. (1998) Development and growth of the skull in the southern fur seals Arctocephalus forsteri and A. pusillus doriferus (Carnivora: Otariidae). Australian Journal of Zoology 46: 43-66.

BRUNNER, S. (2000) Cranial morphometrics of fur seals and sea lions (Family: Otariidae) - systematics, geographic variation and growth. PhD thesis, University of Sydney, Australia. 280pp.

CAmpagna, C. (2002) Aggressive Behavior (intraspecific). Pages 1316 in PerRIN, W. F., WÜRSIG, B. AND ThEWISSEN, J. G. M. (Eds) Encyclopedia of Marine Mammals. Academic Press, San Diego, California.

Campagna, C. and Le Boeuf, B. J. (1988) Thermoregulatory behavior in southern sea lions and its effect on the mating system. Behaviour 107: 72-90.

Crespo, E. A. (1984) Dimorfismo sexual en los dientes caninos y en los cráneos del lobo marino del sur, Otaria flavescens (Shaw) (Pinnipedia, Otariidae). Revista del Museo Argentino de Ciencias Naturales "Bernardino Rivadavia", Serie Zoologia 13: 245-275.
Drehmer, C. J. AND Ferigolo J. (1996) Descrição do sincrânio de Arctocephalus australis (Pinnipedia, Otariidae). Iheringia, Série Zoologia (81): 63-74.

Drehmer, C. J. AND Ferigolo J. (1997) Osteologia craniana comparada entre Arctocephalus australis e A. tropicalis (Pinnipedia, Otariidae). Iheringia, Série Zoologia (83): 137 - 149.

Hingst-Zaher, E., Marcus, L. F. and Cerqueira, R. (2000) Application of geometric morphometrics to the study of postnatal size and shape changes in the skull of Callomys expulsus. Hystrix 11: 99-114.

Kerley, G. I. H. and Robinson, T. J. (1987) Skull morphometrics of male Antarctic and Subantarctic fur seals, Arctocephalus gazella and A. tropicalis, and their interspecific hybrids. Pages 121-131 in Croxall, J. P. and Gentry, R. L. (Eds) Status, Biology and Ecology of Fur Seals, Proceedings of an International Symposium and Workshop. Cambridge, United Kingdom, 23-27 April 1984.

KING, J. E. (1954) The otariid seals of the Pacific Coast of America. Bulletin of British Museum of Natural History 2: 309-337.

KING, J. E. (1983) Seals of the World. British Museum (Natural History), Cornell University Press, London, United Kingdom. 240pp.

Kovacs, K. M. and Lavigne, D. M. (1992) Maternal investment in otariid seals and walruses. Canadian Journal of Zoology 70: 1953-1964.

Le Boeuf, B. J. and Laws, R. M. (1994) Elephant seals: Population Ecology, Behavior, and Physiology. University of California Press, Berkeley, California.

Lindenfors, P., Tullberg, B. And Biuw, M. (2002) Phylogenetic analyses of sexual selection and sexual size dimorphism in pinnipeds. Behavior, Ecology and Sociobiology 52: 188-193.

Majluf, P. (1987a) South American fur seal, Arctocephalus australis, in Peru. Pages 23-27 in CROXALl, J. P. AND Gentry, R. L. (Eds) Status, Biology, and Ecology of fur seals. Proceedings of the International Symposium and Workshop. Cambridge, United Kingdom, 23-27 April 1984.

Majluf, P. (1987b) Reproductive ecology of female South American fur seals at Punta San Juan. Ph.D. thesis, University of Cambridge, King's College, Cambridge, United Kingdom. 127pp.

MajLuf, P. (1992) Timing of births and juvenile mortality in the South American fur seal in Peru. Journal of Zoology, London 227: 367-383.

Marcus, L. F. (1990) Traditional morphometrics. Pages 77122 in Rohlf, F.J. and Bookstein, F.L. (Eds). Proceedings of the Michigan Morphometrics Workshop. The University of Michigan, Michigan.

Marcus, L., Bello E. and García-Valdecasas, A. (1993) Contributions to morphometrics. Monografias del Museu Nacional de Ciencias Naturales 8, Madrid, Spain. 240pp.

Molina-Schiller, D. (2000) Idade e desenvolvimento craniano do lobo-marinho-do-sul, Arctocephalus australis (Zimmermann, 1783) (Carnivora: Otariidae), no litoral do Rio Grande do Sul. M.Sc. thesis, Fundação Universidade do Rio Grande, Rio Grande, Brazil. 117pp.

Molina-Schiller, D. And Pinedo, M. C. (2004a) Using canine teeth for sex determination of the South American fur seal, Arctocephalus australis. The Latin American Journal of Aquatic Mammals 3(1):19-24. 
Molina-Schiller, D. And Pinedo, M. C. (2004b) Growth layer pattern in Arctocephalus australis canine teeth: evaluation of techniques for age determination. The Latin American Journal of Aquatic Mammals 3(2):95-105.

Monteiro-Filho, E. L. A., Monteiro, L. R. And Reis, S. F. (2002) Skull shape and size divergence in dolphins of the genus Sotalia: a tridimensional morphometric analysis. Journal of Mammalogy 83: 125-134.

Moritz, C. (1994) Defining evolutionary significant units for conservation. Trends in Ecology and Evolution 9: 373-375.

Naya, D. E., Arim, M. And Vargas, R. (2002) Diet of South American fur seals (Arctocephalus australis) in Isla de Lobos, Uruguay. Marine Mammal Science 18: 734-745.

Neff, N. A. And Marcus, L. F. (1980) A Survey of Multivariate Methods for Systematics. American Society of Mammalogy. 243pp.

OliveirA, L. R. (2004) Variação geográfica do lobo-marinho sulamericano, Arctocephalus australis (Zimmermann, 1783) com base em dados morfológicos e moleculares. PhD. thesis, Instituto de Biociências/ Universidade de São Paulo, São Paulo, Brazil. 217pp.

Oliveira, L. R., Malabarba, L. R. And Majluf, P. (1999) Variação geográfica em crânios do lobo-marinho sul-americano Arctocephalus australis (Zimmermann, 1783) das populações do Brasil e Peru. Comunicações do Museu de Ciência e Tecnologia da PUCRS, Série Zoologia 12: 179-192.

Ralls, K. and Mesnick, S. (2002) Sexual dimorphism. Pages 1071-1077 in Perrin, W. F., WÜrsig, B. And Thewissen, J. G. M (Eds) Encyclopedia of Marine Mammals . Academic Press, San Diego, California.

Rensch, B. (1950) Die Abhängigkeit der relativen Sexualdifferenz von der Körpergro. Bonner Zoologische Beiträge 1: 58-69.

Reppenning, C. A., Peterson, R. S. and Hubbs, C. L. (1971) Contributions to the systematics of the southern fur seals, with particular reference to the Juan Fernández and Guadalupe species. Antarctic Pinnipedia, Antarctic Research Series, Wanshington D.C. 18: 1-34

Riedman, M. L. (1990) The Pinnipeds. Seals, Sea Lions and Walruses. University of California Press, Berkeley, California.

RoHLF, F. J. (1993) Relative warps analysis and an example of its application to mosquito wings. Contributions to morphometrics. Monografias del Museu Nacional de Ciencias Naturales 8, Madrid, Spain. 240pp.

Rohlf, F. J. (2000) Tps Regr, ver. 1.25 ( ) 2000, F. James Rohlf. Dept. Ecology and Evolution, State University of New York at Stony Brook.

Rohlf, F. J. (2002) TpsRelW, ver. 1.25. (C) 2002, F. James Rohlf. Dept. Ecology and Evolution, State University of New York at Stony Brook.
Rohlf, F. J. (2003) TpsDig, ver. 1.32 @ 2003, F. James Rohlf. Dept. Ecology and Evolution, State University of New York at Stony Brook.

Rohlf, F. J. And Marcus, L. F. (1993) A revolution in morphometrics. Trends in Ecology and Evolution 8(4): 129-132.

SANFelice, D. (2004) Ontogenia craniana comparada de Arctocephalus australis, Callorhinus ursinus $e$ Otaria byronia (Otariidae: Pinnipedia). Ph.D. Thesis. Univeridade Federal do Rio Grande do Sul (UFRGS). Porto Alegre, RS, Brazil. 153pp.

Schiavini, A. C. M. (1992) Growth structures of maxillary canines of the southern fur seal (Arctocephalus australis). Marine Mammal Science 8(1): 89-93.

Sivertsen, E. (1954) A survey of the eared seals (family Otariidae) with remarks on the Antarctic seals collected by M/K Norvegia in 1928-1929. Oslo: Det Norske VidenskapsAkademi i Oslo (Scientific Results of the Norwegian Antarctic Expeditions 1927-1928 et sqq, no. 28).

SlICE, D. E. (1994) GRF-ND, Generalized rotational fitting of n-dimensional landmark data. Dennis E. Slice. Dept. Ecology and Evolution, State University of New York at Stony Brook.

SLICE, D. E. (1999) Morpheus et al. @ Dennis E. Slice. Dept. Ecology and Evolution, State University of New York at Stony Brook.

StirLing, I. (1983) The evolution of mating systems in pinnipeds. Pages 489-587 in Eisenberg, J. F. and Kleiman, D.G. (Eds). Advances in the Study of Mammalian Behavior. American Society of Mammalogists Special Publication No. 7.

SzTeren, D., NAya, D.E. AND ArIm, M (2004) Overlap between pinniped summer diet and artisinal fishery catches in Uruguay. The Latin American Journal of Aquatic Mammals 3(1): 19-24.

Trillmich, F. (1996) Parental investment in pinnipeds. Pages 533-577 in Rosenblatt, J. S. and Snowdon, C. T. (Eds) Parental Care: Evolution, Mechanisms and Adaptive Significance Academic Press, San Diego, California.

Vaz-Ferreira, R. (1982) Arctocephalus australis Zimmerman, South American fur seal. in Mammals in the Seas. FAO Fisheries series, Small cetaceans, seals, sirenians and otters 4: 497-508.

WeCKERLy, F. W. (1998) Sexual-size dimorphism: influence of mass and mating systems in the most dimorphic mammals. Journal of Mammalogy 79: 33-52.

Ximenez, I. M., Lima, M., Ponce De Léon, A., Batallés, L. M. AND MALEK, A. (1984) Estudio de las relaciones craneales en "lobo fino" sudamericano, Arctocephalus australis (Zimmermann, 1783). Pages 3-33 in Anales de La Industria Lobera y Pesquera del Estado (I.L.P.E). Montevideo, Uruguay.

XimeneZ, I. M. AND LangGuth, E. (2002) Isla de Lobos. Graphis editora. Montevideo, Uruguay. 231PP.

Zimmerman, E. A. W. Von (1783) Geographische Geshichte des Menschen, und der Allgemeiss Verbreiteten Vierfüssigen Thiere, Leipzig. 3: 1778-1783. 


\begin{abstract}
Appendix I
Specimens examined.-The 386 adult specimens used in this study were obtained from the following collections: Grupo de Estudos de Mamíferos Aquáticos do Rio Grande do Sul, Brazil (GEMARS: 0173;176; 0185; 208; 0218; 0256; 0259; 0263; 0278; ;0280; 0293; 0297; 0298; 0302; 0308; 0316; 0321; 0338; 0359; 0361; 0364; 0368; 0425; 0429; 0436; 0439; 0445; 450; 0537; 0542; 0544; 0558; 0561; 0578; 0581; 0582; 0584; 0586; 0589; 0639; 0655; 0661; 0681; 0694; 0706; 0717; 0721; 0726; 0733; 0732; 0739; 0801), Museu de Ciências Naturais da Fundação Zoobotânica do Rio Grande do Sul, Brazil (MCN-FZB: 2630; 2637; 2688; 2699; 2706; 2886), Laboratório de Mamíferos Aquáticos da Universidade Federal de Santa Catarina, Brazil (LAMAQ-UFSC: 1057; 1063; 1133;1135;1142; 1143; 1149; 1153; 1154; 1156; 1157; 1158; 1159; 1160; 1163; 1166; 1167; 1169; 1170; 1228; 1274), Laboratório de Mamíferos Aquáticos e Tartarugas Marinhas da Fundação Universidade do Rio Grande, Brazil (LMM-FURG: s/no.7; 0101; 0483; 0491; 0508; 0608; 0609; 0663; 0684; 0726; 0731; 0732; 0740; 0750; 0754; 0836; 0840; 0863; 0890; 1065; 1113; 1215; 1252; 1258; 1282; 1283; $1331 ; 1336 ; 1338 ; 1340 ; 1341 ; 1342 ; 1346 ; 1431 ; 1435 ; 1437 ; 1438 ; 1442 ; 1444 ; 1464 ; 1535 ; 1549 ; 1554 ; 1657 ; 1676 ; 1680 ;$ $1681 ; 1690 ; 1697 ; 1700 ; 1738 ; 1742 ; 1748 ; 1781 ; 1808 ; 1813 ; 1815 ; 1824 ; 1859 ; 1866 ; 1885 ; 1898 ; 1903 ; 1985 ; 2039 ; 2041 ;$ 2042; 2043; 2045; 2084; 2121; 2258; 2259; 2263; 2264; 2267; 2275), Centro Nacional Patagónico, Argentina (CENPAT: Aa16), American Museum of Natural History, USA (AMNH: 205916; 205917; 205918; 254561; 254562; 254563; 254564; 254565; 254567; 254568; 254569), Facultad de Ciencias Naturales, Uruguay (FCN: 0336; 1522; 1527; 1530; 1538; 1552; 1580; AL840; DS23), National Museum of Natural History - Smithsonian Institution, USA (NMNH: 484934; 484935; 501120; 504895), British Museum of Natural History, UK (BMNH: 1947.7.16.4; 1984.911; 1984.912; 1984.918; 1984.920; 1984.921; 1984.923; 1984.924; 1984.926; 1984.927; 1984.928; 1984.930; 1984.931; 1984.932; 1984.933; $1984.934 ; 1984.935 ; 1984.939 ; 1984.942 a ; 1984.947 ; 1984.948 ; 1984.949 ; 1984.969 ; 1984.972 ; 1984.973 ; 984.975 ; 1984.978 ;$ 1984.910; 1984.914; 1984.915; 1984.916; 1984.917; 1984.919; 1984.922; 1984.925; 1984.937; 1984.938; 1984.940; 1984.942; 1984.957; 1984.965; 1984.967; 1984.968; 1984.970; 1984.974) and Proyecto Punta San Juan, Perú (PSJ: 0002; 0003; 0004; 0005; 0006; 0007; 0008; 0009; 0016; 0073; 0074; 0075; 0076; 0078; 0079; 0080; 0096; 0102; 0104; 0113; 0115; 0119; 0143; 0144; 0168; 0169; 0170; 0171; 0172; 0173; 0175; 0176; 0177; 0178; 0179; 0180; 0208; 0209; 0210; 0216; 0217; 0218; 0219; 0220; 0221; 0222; 0223; 0224; 0225; 0233; 0234; 0236; 0237; 0238; 0239; 0240; 0241; 0242; 0243; 0244; 0245; 0261; 0262; 0263; 0264; 0265; 0266; 0267; 0268; 0269; 0270; 0271; 0272; 0273; 0274; 0275; 0276; 0277; 0287; 0288; 0289; 0290; 0291; 0293; 0294; 0295; 0297; 0298; 0300; 0302; 0304; 0306; 0307; 0312; 0314; 0315; 0316; 0319; 0320; 0321; 0322; 0323; 0324; 0325; 0326; 0327; 0328; 0329; 0330; 0331; 0332; 0333; 0334; 0335; 0336; 0338; 0358; 0359; 0360; 0361; 0362; 0363; 0364; 0365; 0366; 0367; 0368; 0369; 0370; 0371; 0372; 0373; 0374; 0375; 0376; 0377; 0378; 0379; 0391; 0410; 0411; 0412; 0413; 0414; 0415; 0417; 0418; 0436; 0447; 0448; 0449; 0450; 0460; 0461; 0462; 0463; 0464; 0465). The specimens were grouped by sex and population origin: Uruguay (134 $\sigma^{\prime \prime}$ and 49 오 ) and Peru (101 $\sigma^{\prime \prime}$ and 102 오 ).
\end{abstract}

